\title{
Crop-specific technology extrapolation domains for Brazil
}

\author{
Felipe Augusto Andrade Soares ${ }^{1}$ (D), Fábio Ricardo Marin ${ }^{1, *}$ \\ 1. Universidade de São Paulo - Escola Superior de Agricultura "Luiz de Queiroz" - Departamento de Engenharia de Biossistemas - Piracicaba \\ (SP), Brazil. \\ Received: Jul. 3, 2020 | Accepted: Oct. 6, 2020 \\ Section Editor: Gabriel Constantino Blain \\ *Corresponding author: fabio.marin@usp.br \\ How to cite: Soares, F. A. A. and Marin, F. R. (2021). Crop-specific technology extrapolation domains for Brazil. Bragantia, 80, e0321. https:// \\ doi.org/10.1590/1678-4499.20200310
}

\begin{abstract}
Climate and soil databases can be used for delineating homogenous environmental zones over large areas of agricultural land to support agricultural research planning and spatial extrapolation of the results of field experiments. In other countries, such framework has proven useful to improve the efficiency and impact of investments in agricultural research. Furthermore, this approach can also contribute to identify key locations with the greatest potential for spatial extrapolation in terms of crop production area with similar climate and soils. In this paper, soil and weather databases covering the main agricultural land in Brazil were developed, and crop-specific technology extrapolation domains (TEDs) were identified for maize, soybean, and sugarcane crops. These databases were useful and viable option for the generation of homogeneous zones maps for different crops and regions. Given the spatial scale of the database applied, it was possible to represent a large area in few TEDs, without losing information regarding climate and soil variability, facilitating the spatial extrapolation of technologies throughout Brazil. Few TEDs are needed to represent a large part of the area of sugarcane ( 32 TEDs to cover $51 \%$ of the area), maize (21 TEDs for $51 \%$ of the area), and soybean (17 TEDs for $50 \%$ of the total area). Such information may help several areas of the agricultural sector, such as supporting new research that works on areas with large scales, or areas not explored yet.
\end{abstract}

Key words: agricultural zoning, homogenous zones, soybean, maize, sugarcane.

\section{INTRODUCTION}

Average crop yields need to increase during the next decades to meet the expected increase in food demand while avoiding crop expansion (Mourtzinis et al. 2018). Brazil has one of the world's largest reserves of agricultural land, the fastest agricultural expansion during the $21^{\text {st }}$ century, enormous natural resources, and a robust agricultural industry (FAO 2015).

Around 30\% of Brazilian gross domestic product (GDP) depends on the agricultural sector (Martinelli et al. 2010), while agricultural research expends a considerable amount of resources from both the private and public sectors. Research on agriculture as a driver of economic development has been widely recognized due to the cross-sectoral linkages between agriculture and nonagricultural economic sectors (Tiffin and Irz 2006). In general, studies on crop responses to management strategies such as type of cultivars, and use of fertilizers and herbicides are usually restricted to the local scale due to specific characteristics of soil and climate (van Wart et al. 2013). Large amounts of public and private resources are expended yearly for collecting data from experimental field trials, either for testing scientific hypotheses or for evaluating new commercial products before releasing them onto the market (Pardey et al. 2006).

Most of Brazilian agriculture has undergone high rates of expansion over the last four decades in the central area of the country. Even on traditional agricultural regions, however, there is a lack of knowledge on how soil and climate control crop 
growth and development at large scales, which would allow public and private decision makers to select where experiments should be established for more efficient resources use. For most of Brazil's agricultural land, high quality climate and soil data at fine spatial resolution are not available for large important areas, and obtaining these data at many locations will be costly, laborious, and requires a long time for field studies and data acquisition. Such a lack data might limit the understanding of crop behavior and potential factors limiting producer yields (Edreira et al. 2017). Therefore, an upscaling method can be a type of "bottom-up" approach from location-specific observed data to larger spatial areas, seeking that the scale chosen should be small enough to minimize variation in climate and crop management practices and large enough to minimize data collection at regional scale (van Ittersum et al. 2013).

Van Wart et al. (2013) conducted a study on a global scale to seek an appropriate method using upscaling methodology based on the approach of homogeneous climate zones (CZ) and their climatic components, which can be used as a robust guide for analyzing large areas of agricultural interest. Edreira et al. (2018) developed a framework for the US agriculture, called technology extrapolation domains (TED), by using CZs and soil databases within a spatial analysis framework for identifying homogenous zones for crop growth and development in order to support agricultural research planning. Such a framework is useful to improve the efficiency and impact of investments in agricultural research, the more so because it is possible to customize it by adding other variables, including socioeconomic variables that are relevant for out-scaling and adoption of technology. Furthermore, such an approach can also contribute to identify key locations with the greatest potential for spatial extrapolation in terms of crop production area with similar climate and soils, as well as to select the number of sites needed to cover a particular region to be commercially addressed by a company. Finally, such a spatial framework to delineate regions in which crop production technologies perform similarly may overcome the limitations of extrapolation of the results of agronomic field experiments (Edreira et al. 2018).

Brazil is still lacking a spatial framework to guide technology transfer in cropping systems. In this paper, soil and weather databases covering the main agricultural land in Brazil were developed, following the protocols of Edreira et al. (2018). The noncrop specific CZs worldwide provided by van Wart et al. (2013), which were based on large scale weather gridded data, were refined by using crop-specific relatively more detailed CZs based on locally measured weather data. The specific objectives were to identify the TEDs for maize, soybean, and sugarcane crops in Brazil, in order to offer a spatial guide for policy makers and private companies to strategically plan agricultural research and experimental results extrapolation.

\section{MATERIAL AND METHODS}

\section{Study region and database}

A database for soil and climate was developed covering 21 out of 26 states of Brazil and comprising the main agricultural area of the country. For climate, we used a grid of weather stations with well distributed daily data with an average resolution of $10 \mathrm{~min}$ (Fig. 1). The climate database used was constituted by 3,159 weather stations distributed across the main agricultural states of Brazil and organized as average monthly values of rainfall, and maximum and minimum air temperature. This database was based on daily weather data provided by several sources such as the National Institute of Meteorology (INMET), National Water Agency (ANA), University of São Paulo (USP), Brazilian Agricultural Research Enterprise (Embrapa), Agronomic Institute of Paraná (IAPAR), Department of Water and Electrical Energy (DAEE), and Agronomic Institute of Campinas (IAC). The weather data can be accessed in a spatial aggregated form in shapefile format at https://www.esalq.usp.br/gepema/teds/.

Some weather stations have only rainfall data available, it being necessary to estimate maximum, minimum, and average temperatures. For those, the methodology proposed by Alvares et al. (2013a) was used, which correlates temperatures with geographical coordinates (latitude and longitude) and altitude in Brazil, according to Eq. 1:

$$
T i=a o+a 1 \varphi+a 2 \gamma+a 3 \mathrm{~h}+a 4 \varphi \gamma+a 5 \varphi h+a 6 \gamma h+a 7 \varphi^{2}+a 8 \gamma^{2}
$$

where: $T i$ is minimum, maximum, and average temperature, monthly temperature ( $i=1,2,3 \ldots, 12), \varphi$ is latitude in decimal degrees, is longitude in decimal degrees, $h$ is altitude in meters, and to are the coefficients of the multiple regression equation. 


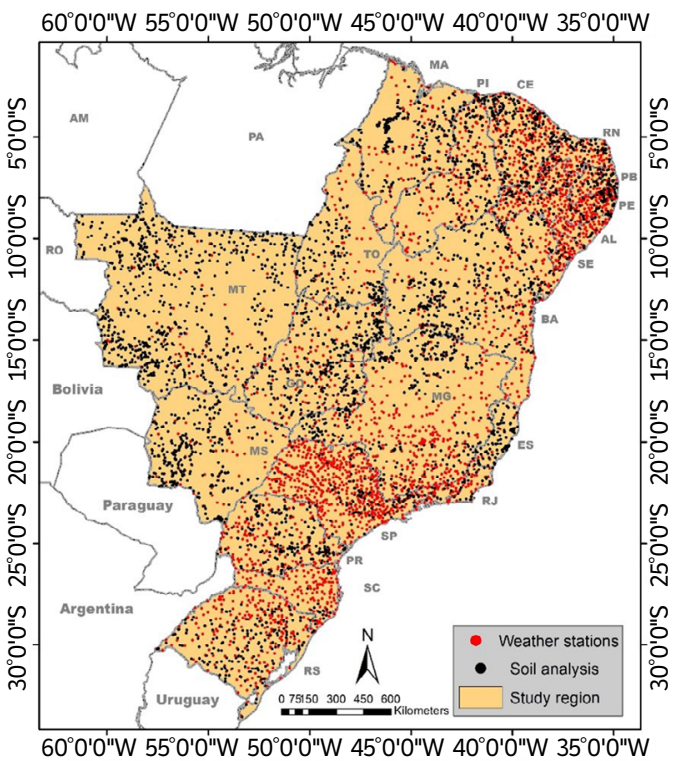

Figure 1. Spatial distribution of soil data points used for estimating the total available soil water and the weather stations used for creating the homogenous CZs.

Following Edreira et al. (2018), the analysis of climatic features of each region was based on four variables: (i) annual total growing degree-days (GDD), which determines the length of the crop growing season; (ii) annual temperature seasonality, which differentiates between temperate and tropical climates; (iii) aridity index, which defines the water limitation in rainfed crop growing; and (iv) total available water (TAW) in the rootable soil depth, which determines the ability of the soil to supply water to support crop growth during rain-free periods, in which a root depth of $120 \mathrm{~cm}$ for sugarcane, $100 \mathrm{~cm}$ for maize, and $60 \mathrm{~cm}$ for soybean (Allen et al. 1998) was used. Therefore, each TED would correspond to a combination of these four variables.

To calculate the growing degree-days (GDD) for sugarcane, a base temperature at monthly time step data suggested by Marin et al. (2014) was used, adopting a temperature base of $19.0^{\circ} \mathrm{C}$ for sugarcane Marin et al. (2014) as follows:

For conditions in which the $T M>T b>T m$, Eq. 2 was used:

$$
G D D=\frac{(T M-T b)^{2}+(T M-25)^{2}}{2(T M-t m)} x f \times N D
$$

and for $T b<T m$ :

$$
G D D=T M-T+\frac{(T m-T b)}{2}+\frac{(T M-25)^{2}}{2(T M-t m)} \times f \times N D
$$

in which,

$$
f=\left(\frac{N}{N-24}\right)^{2}
$$

where $T M$ is average maximum temperature $\left({ }^{\circ} \mathrm{C}\right), T m$ is average minimum temperature $\left({ }^{\circ} \mathrm{C}\right), \mathrm{Tb}$ is base temperature $\left({ }^{\circ} \mathrm{C}\right)$, $N$ is the length of the days in hours, and $N D$ is number of days. 
For soybean and maize, GDD were calculated according to Licker et al. (2010), adopting a temperature base of $14.0^{\circ} \mathrm{C}$ for soybean (Pascale et al. 1973) and $8.0^{\circ} \mathrm{C}$ for maize (Warrington and Kanemasu 1983) as follows in Eq. 5 :

$$
G D D=\sum_{i=1}^{365} \max (0 . T i-t b)
$$

where $T i$ is average temperature $\left({ }^{\circ} \mathrm{C}\right)$ and $T b$ is base temperature $\left({ }^{\circ} \mathrm{C}\right)$.

Temperature seasonality was calculated as the standard deviation of the average monthly temperatures $\times 100$ (van Wart et al. 2013). The aridity index was calculated by the division between the mean annual precipitation and reference evapotranspiration (ETo), which was based on the approach developed by Camargo et al. (1999) (Eq. 6), which in turn was proven to be well calibrated for the whole of Brazil:

$$
E T o=0.01 \frac{Q o}{2.45} \cdot(1.08 . T M-0.36 . T m)
$$

where ETo is the reference evapotranspiration $\left(\mathrm{mm} \cdot \mathrm{day}^{-1}\right), Q o$ is extraterrestrial solar irradiation $\left(\mathrm{MJ} \cdot \mathrm{m}^{-2} \cdot \mathrm{d}^{-1}\right), T M$ is monthly average maximum temperature $\left({ }^{\circ} \mathrm{C}\right)$, and $\operatorname{Tm}$ is average minimum temperature $\left({ }^{\circ} \mathrm{C}\right)$.

As described, after creating the CZ following van Wart et al. (2013), the CZ were generated for the analyzed area in Brazil by combining with TAW to better represent the environmental conditions for the development and growth of the major crops grown in Brazil (van Bussel et al. 2015). Soil and climate databases were interpolated using the ordinary kriging method with pixel size of $10 \mathrm{~min}$. For the estimates of the TAW in the soil, pedotransfer functions provided by Tomassella et al. (2000) were used to estimate soil hydraulic parameters required, following the approach of van Genuchten (1980), from soil texture, organic carbon content, and soil density, as provided by the soil databases of the Radambrasil Project (Brazil 1973-1986) and Cooper et al. (2005) (Fig. 1). Compared to the soil database used by Edreira et al. (2018), soil database can be considered too coarse, which represents a limitation for the study and it should be the focus of future studies to make the soil databases available for Brazil denser and more detailed.

\section{Defining technological extrapolation domains for Brazil intervals and polygons}

As mentioned, each TED can be assumed as a combination of CZ with the TAW in the rootable soil depth. Each climate variable had its own classes considering the spatial variability observed throughout the analyzed region of this study and for each crop. After Edreira et al. (2017), some small areas within CZs were assumed as irrelevant for the study scheme, and two criteria were used to decide when to remove such polygons: those smaller than 350,000 ha and those having areas five times lower than the surrounding CZs.

\section{Validating the technological extrapolation domains for Brazil}

For validating the Brazilian TEDs of each crop, a survey of yield at municipality scale provided by the Brazilian Institute of Geography and Statistics (IBGE, http://www.sidra.ibge.gov.br) was used. Data from the last 10 years were used and the yield data for each TED component (climate and soil zones) were spatially aggregated, assuming that within each TED the yield variability is lower than the variability among TEDs. Moreover, the growing area data for each crop were used to define the number of TEDs necessary to represent the fraction of total area for maize, soybean, and sugarcane. Finally, comparisons among yield means associated with selected TED across Brazil were performed using the Tukey's test $(\mathrm{p}<0.05)$. 


\section{RESULTS AND DISCUSSION}

\section{Homogenous climate and soil zones}

The GDD maps were closely related to temperature spatial variation in Brazil, with areas close to the Equator having higher GDD and no limitation for crop development through the year (Fig. S1). In high latitude areas in the south of Brazil, however, the maps showed some limited availability of GDD for growing crops in specific periods of the year, because of temperature seasonality. Given the wide range of latitudes where maize, soybean, and sugarcane have been cultivated in Brazil, the number of classes were considered adequate to represent the environmental spatial variability of the country. Such variability implies the need to select the right genotypes for each production zone, which is demonstrated by the diversity of genotypes offered to growers by private companies and public institutions in Brazil (Bustos et al. 2016). The differentiation in terms of GDD is also important for improving crop management, such as weeds, diseases, and pest control (López-Ovejero et al. 2005).

Related to the GDD maps (Fig. S1), but not with the same meaning, annual temperature seasonality maps show the variation of temperature throughout the year, in which regions near to the Equator line presented lower temperature variation than subtropical regions in southern Brazil (Fig S2a). The aridity index is an indicator of the level of dryness of the climate at a given location. Thus, areas with low rainfall and high temperature presented high degree of dryness (or low aridity index). On the other hand, areas with high rainfall and low temperature indicate a lower dryness degree (or a higher aridity index). The aridity index map (Fig. S2b) represented the spatial variability of Brazil well in terms of water availability, contrasting the humid regions in southern Brazil with the semiarid zones in northeast Brazil. This spatial distribution conforms with the natural biome distribution in Brazil and the climate classification of the country (Alvares et al. 2013b).

By intersecting GDD maps for each crop, seasonal temperature, and aridity index, maps of crop-specific climatic zones (CZs) were created. In total, in Brazil, there are $85 \mathrm{CZs}$ for maize, $84 \mathrm{CZs}$ for soybean, and $91 \mathrm{CZs}$ for sugarcane in the main agricultural states of Brazil (Fig 2). Compared with the number of CZs provided by van Wart et al. (2013) for Brazil, a higher number of CZs was found due to the higher resolution of the weather database used for mapping the GDD (Fig. S1), aridity index (Fig. S2a), and temperature seasonality (Fig. S2b). van Wart et al. (2013) used lower resolution gridded data and provided a worldwide framework for defining homogenous $\mathrm{CZs}$, and that is the reason for the relatively lower resolution of their map.

Total available soil water (TAW) is basically related to the type of soil and physical characteristics, in which soils with higher clay content showed higher storage capacity, while less structured soils and sandy soils present less water storage capacity (Fig S3). The maps show soils in important productive regions of Brazil storing large amounts of water, and this could explain the good performance of agriculture in these regions. Intersecting CZs with TAW (Fig. 3) resulted in a total of 199 TEDs for maize, 201 TEDs for soybean, and 245 TEDs for sugarcane. This is the number of zones required to cover the main agricultural states of Brazil for the different crops and is essential for the efficient evaluation of a new technology to ensure that the number of field experiments can be reduced by covering larger scales based on climate and soil type. This number of TEDs is not considered high for a large country such as Brazil (Fig. 3). Rather, it is reasonable for rationalizing the number and location of experiments, and would be useful for providing spatial guidance to reduce the number of experiments to a minimum while representing Brazilian environmental diversity. For instance, considering that soybean has been cultivated on c.a. 35 million ha in the last season in Brazil and that such a large area could be represented by only 136 TEDs (Fig. 3), this information will help policy makers and companies to better plan research resources, retaining experimental sites that are well located and moving other experimental sites to locations that are not currently represented. Edreira et al. (2018) found 620 and 1,140 TEDs for moderate and high resolution, respectively. Comparatively, the low number of TEDs found for Brazil is mainly related to the low resolution of the soil data used for mapping the crop-specific TAW (Fig. S3). 
(a)

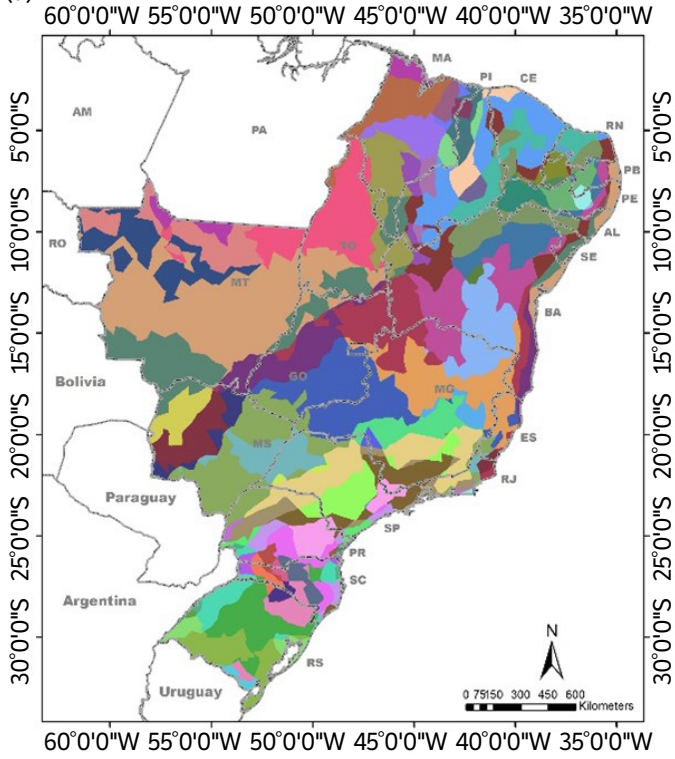

(b)

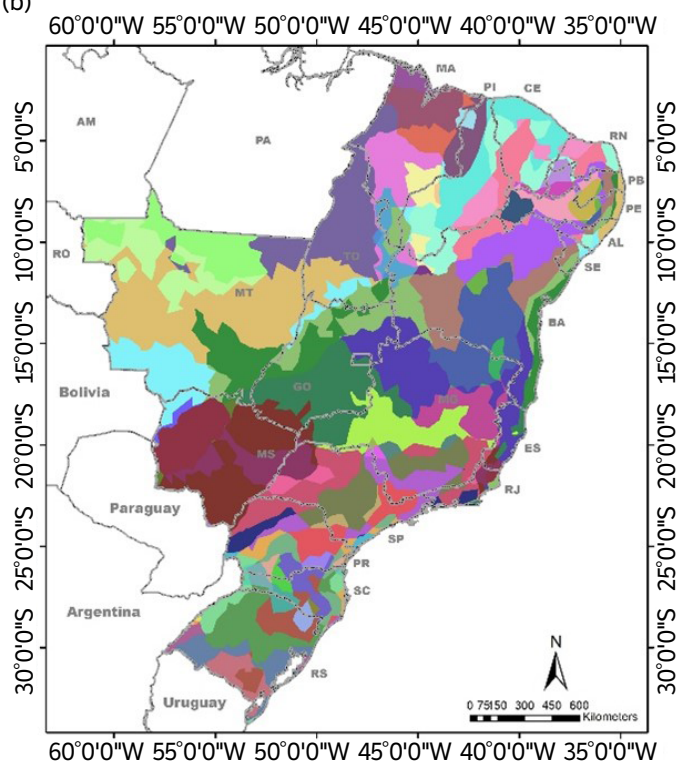

(c)

(c) $60^{\circ} 0^{\prime} 0^{\prime \prime} \mathrm{W} 55^{\circ} 0^{\prime} 0^{\prime \prime} \mathrm{W} 50^{\circ} 0^{\prime} 0^{\prime \prime} \mathrm{W} 45^{\circ} 0^{\prime} 0^{\prime \prime} \mathrm{W} 40^{\circ} 0^{\prime} 0^{\prime \prime} \mathrm{W} 35^{\circ} 0^{\prime} 0^{\prime \prime} \mathrm{W}$

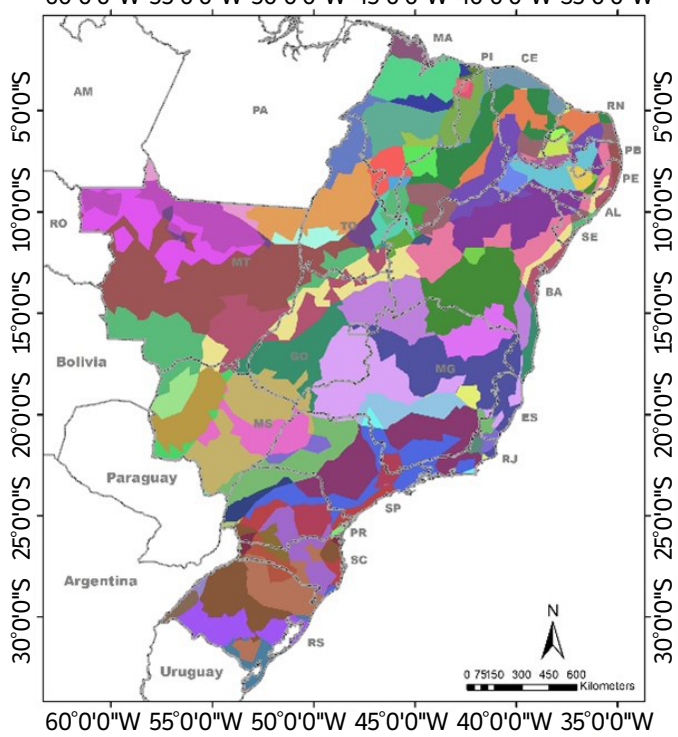

Figure 2. Crop-specific climate zones for maize (a), soybean (b) and sugarcane (c) in the main agricultural States of Brazil.

\section{Planning the location of experimental sites based on the TED approach}

Considering the representativeness of each TED in terms of cultivated area, it was calculated how many TEDs would be needed to represent a fraction of national area for each crop. For instance, only 21 TEDs would be necessary to cover 50.5\% of the total maize area in Brazil (Fig. 4a). Soybean showed the most favorable scenario for saving resources by using the TED approach, as only 17 TEDs would be necessary to represent $50 \%$ of the total soybean area in Brazil (Fig. 4b). For sugarcane, 50 TEDs would be necessary to cover $69 \%$ of the sugarcane growing area in Brazil (Fig. 4c). However, a total of 100 TEDs would be needed to cover more than $94 \%$ of the area, while only 32 TEDs would cover more than $50 \%$ of the total sugarcane area in Brazil (Fig. 4c).

Therefore, it is easy to wonder how much time and resources could be saved by using the TED approach in Brazilian agriculture. These resources are mainly related to agricultural researchers (reduction of work and costs for studies and tests in 
(a)

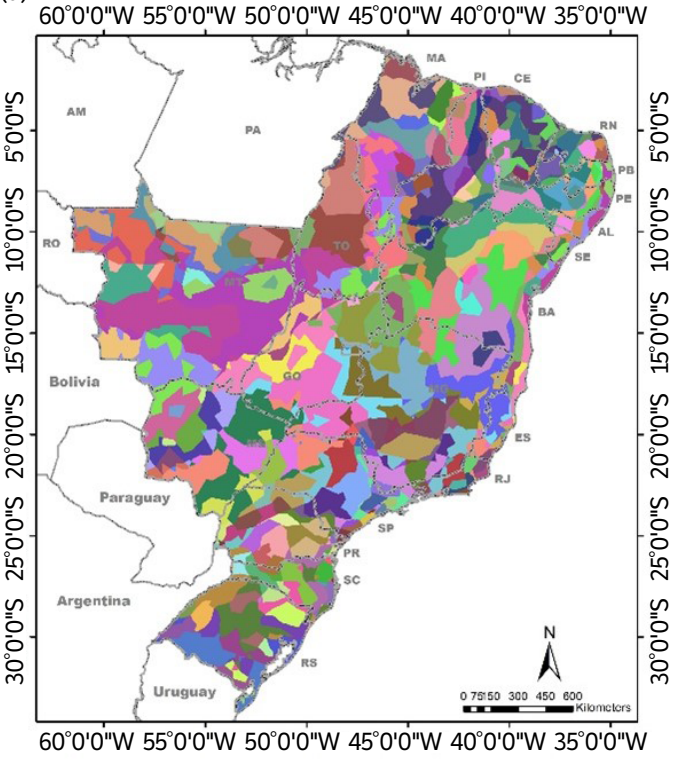

(b)

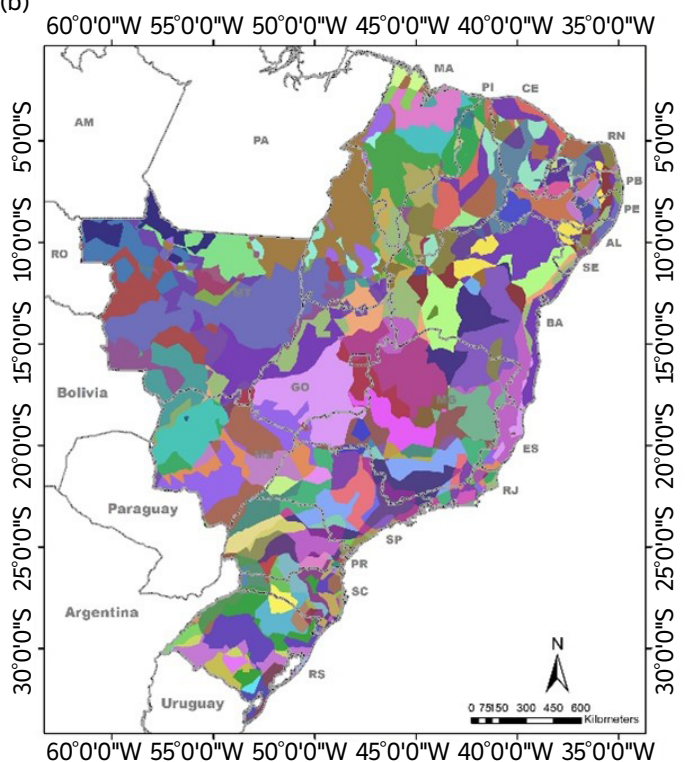

(c)

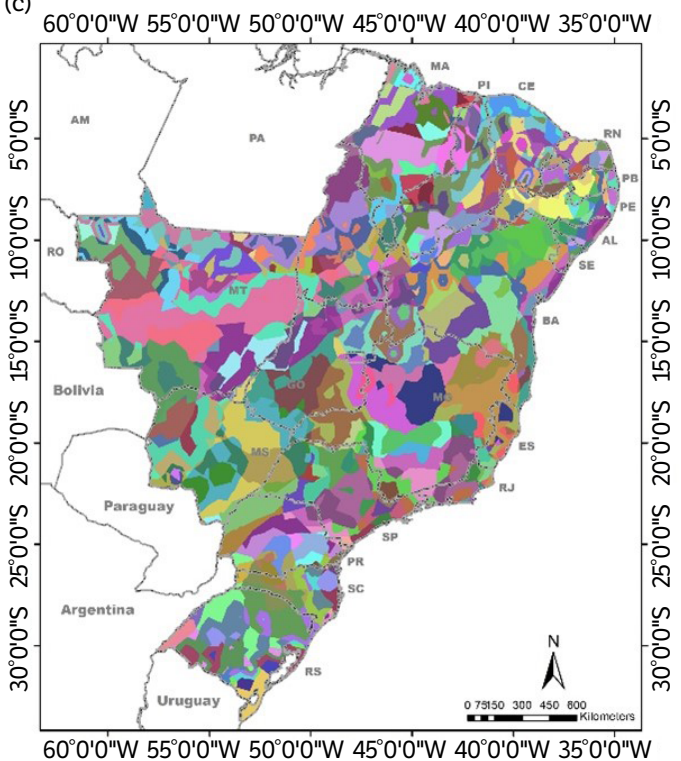

Figure 3. Crop-specific technology extrapolation domains for maize (a), soybean (b) and sugarcane (c) in the main agricultural states of Brazil.

new areas), companies (implementation of existing technologies to other areas), and farms (benchmarking of other regions with similar climate and soil conditions), using this approach of location specific to larger spatial areas (Edreira et al. 2018). This means a massive reduction of experimental sites and costs, as environmental variability can be captured well by only a few TED and experiments should be planned to follow this approach.

\section{Validating the TED approach for Brazil}

As expected, soils with lower TAW presented low average yield when compared to those with higher TAW (Table 1). For example, counties with similar TAW but located in different CZs exhibited significant differences in average yield. Similarly, counties located in the same CZ, but with different TAW exhibited increasing yields in TEDs with greater 
(a)

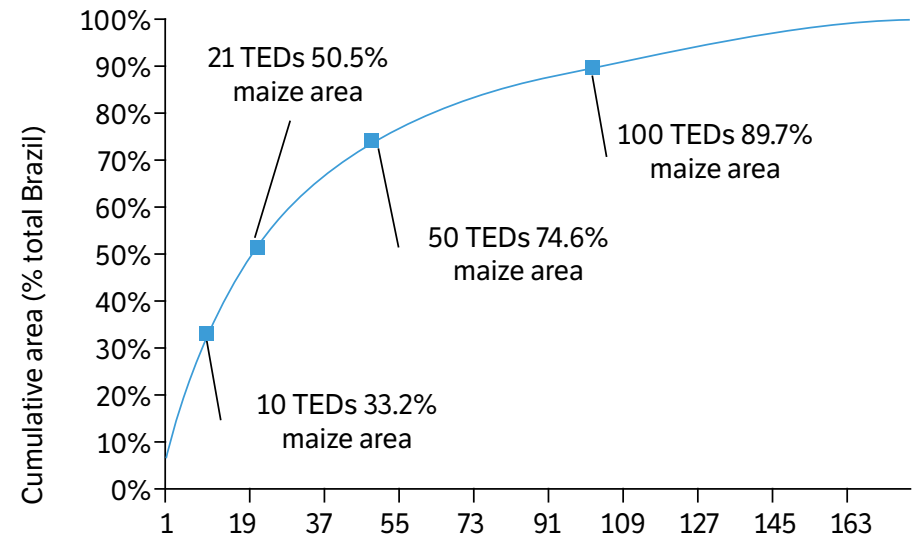

(a)

Number of TEDs
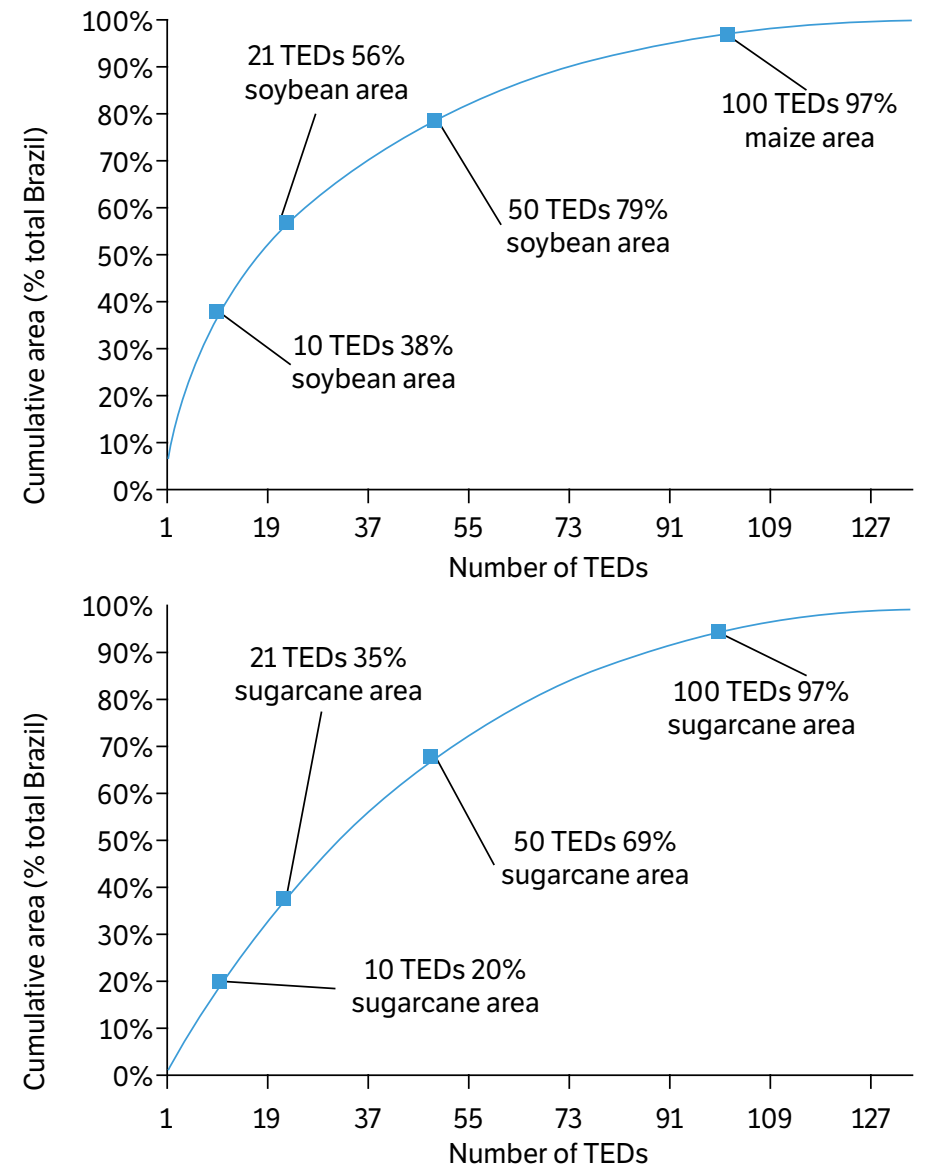

Figure 4. Crop area coverage as a function of number technology extrapolation domains (TEDs). TEDs were sorted fromlargest to smallest according to their 2018 harvested maize (a), soybean (b), and sugarcane (c) area (IBGE, http://www.sidra.ibge.gov.br).

TAW (Table 1). Moreover, the Tukey's test showed that means differed from each other for most TAW classes within each selected CZ, this evidenced that the approach used for classifying CZ and TAW was able to adequately discriminate the environmental differences among different TEDs. Furthermore, the TED maps are also consistent with a well-validated simulation model that accounts for the effects of rainfall, temperature regime, and soil water availability on the crop physiology of sugarcane (Marin et al. 2008; Marin and Carvalho 2012; Marin and Jones 2014, Vianna et al. 2020), maize (Souza et al. 2019), and soybean (Silva et al. 2019). Based on the publicly available weather and soil data in Brazil, it was 
Table 1. Average maize, soybean, and sugarcane yield across selected climate zones (CZ) and total available water (TAW) within each CZ. Means followed by same lower-case letter in the row, and upper-case letter in the column do not differ by Tukey's test $(p<0.05)$.

\begin{tabular}{|c|c|c|c|c|c|c|c|c|c|c|}
\hline & \multirow{2}{*}{$C Z$} & \multicolumn{9}{|c|}{ TAW (mm) } \\
\hline & & 25 & 50 & 75 & 100 & 125 & 150 & 175 & 200 & Mean \\
\hline \multirow{5}{*}{ Sugarcane } & 1 & & & $52.6 a$ & $55.0 a$ & $59.6 a$ & $59.7 a$ & $66.4 b$ & & $58.7 \mathrm{~A}$ \\
\hline & 2 & & & $62.3 a$ & & $69.7 a$ & $70.6 a$ & $72.7 \mathrm{~b}$ & & 68.7B \\
\hline & 3 & & $35.1 a$ & $59.7 \mathrm{~b}$ & $73.2 c$ & $76.5 c$ & & & $112.6 \mathrm{~d}$ & 71.1B \\
\hline & 4 & & & $58.2 a$ & $74.7 \mathrm{~b}$ & $75.6 \mathrm{~b}$ & $78.4 b$ & $80.5 b$ & & $73.5 \mathrm{~B}$ \\
\hline & 5 & & & $70.4 a$ & $76.4 a$ & $77.3 a$ & $77.8 a$ & $79.7 b$ & & $76.3 B$ \\
\hline \multirow{5}{*}{ Soybean } & 6 & $1.91 a$ & $2.01 a$ & $2.07 a$ & $2.16 a$ & & & & & $2.04 \mathrm{~A}$ \\
\hline & 7 & $1.95 a$ & $2.30 a$ & $2.59 \mathrm{~b}$ & $2.83 b$ & & & & & $2.42 \mathrm{~A}$ \\
\hline & 8 & & $2.59 a$ & $2.72 a$ & $3.15 a$ & & & & & $2.82 \mathrm{~B}$ \\
\hline & 9 & $2.64 a$ & $3.01 a$ & $3.04 a$ & $3.28 b$ & & & & & $2.99 B$ \\
\hline & 10 & $2.62 a$ & $3.01 a$ & $3.04 a$ & $3.28 b$ & $3.92 c$ & & & & $3.18 \mathrm{~B}$ \\
\hline \multirow{5}{*}{ Maize } & 11 & & & $2.71 a$ & $3.71 a$ & $4.45 b$ & $4.78 b$ & $4.82 b$ & $5.03 b$ & $4.25 \mathrm{~A}$ \\
\hline & 12 & & & $2.56 a$ & $5.21 b$ & $5.06 c$ & $4.94 c$ & & $5.82 c$ & $4.72 \mathrm{~A}$ \\
\hline & 13 & & & & $4.32 a$ & $5.32 a$ & $5.83 a$ & $5.42 a$ & $5.34 a$ & $5.25 \mathrm{~A}$ \\
\hline & 14 & & & $3.12 a$ & $5.42 b$ & $5.46 b$ & $5.66 b$ & $5.97 b$ & $7.11 \mathrm{c}$ & $5.46 \mathrm{~B}$ \\
\hline & 15 & & & & $5.05 a$ & $4.73 a$ & $6.41 b$ & $6.82 b$ & $7.92 c$ & $6.19 B$ \\
\hline
\end{tabular}

therefore considered that the crop-specific TED framework was able to capture the influence of soil type on yield within the same CZs in Brazil.

\section{CONCLUSION}

Weather and soil databases were found to be a useful and viable option for the generation of homogeneous zones maps for different crops and regions. It was possible to optimize the number of sites in Brazil to represent a large area in a few TEDs, without losing the variations in weather and soil conditions of a crop, facilitating technology transfer to different Brazilian regions. A low number of TEDs are needed to represent a large part of the acreage of sugarcane (32 TEDs to coverage $50.8 \%$ of area), maize (21 TEDs to coverage $50.5 \%$ of area), and soybean (17 TEDs to coverage $50.0 \%$ of acreage).

This study can contribute to several areas of the agricultural sector, such as supporting new research that works in areas with large scales, areas not explored yet, or areas that do not have climate and soil data. The shapefile delineating the TED spatial framework for Brazil is available for downloading at: https://www.esalq.usp.br/gepema/teds/.

Future studies should focus on the use of higher resolution soil data for improving the TAW map quality. Furthermore, the development of TED for other crops would also benefit the Brazilian agricultural industry.

\section{AUTHORS' CONTRIBUTION}

Conceptualization: Marin F. R.; Methodology: Marin F. R. and Soares F. A.; Investigation: Marin F. R. and Soares F. A.; Writing - Original Draft: Soares F. A.; Writing - Review and Editing: Marin F. R. and Soares F. A.; Funding Acquisition: Marin F. R.; Resources, Marin F. R.; Supervision, Soares F. A. 


\section{DATA AVAILABILITY STATEMENT.}

Data is available for downloading at: https://www.esalq.usp.br/gepema/teds/.

\section{FUNDING}

Conselho Nacional de Desenvolvimento Científico e Tecnológico

[http://doi.org/10.13039/501100003593]

Grant No. 425174/2018-2 and 300916/2018-3

Fundação de Amparo à Pesquisa do Estado de São Paulo

[http://doi.org/10.13039/501100001807]

Grant No. 2017/20925-0, 14/12406-4).

\section{ACKNOWLEDGMENTS}

Not applicable.

\section{REFERENCES}

[FAO] Food and Agriculture Organization. (2015). Panorama de la inseguridad alimentaria en América Latina y el Caribe: La región alcanza las metas internacionales del hambre. Rome: FAO. [Accessed Dec. 4, 2020]. Available at: http://www.fao.org/3/a-i4636s.pdf

Allen, R. G., Pereira, L. S., Raes, D. and Smith, M. (1998). Crop evapotranspiration - Guidelines for computing crop water requirements - FAO Irrigation and drainage paper 56. Rome: FAO. [Accessed Dec. 4, 2020]. Available at: https://www.scscourt.org/complexcivil/105CV049053/ volume3/172618e_5xAGWAx8.pdf

Alvares, C. A., Stape, J. L., Sentelhas, P. C. and Goncalves, J. L. M. (2013a). Modeling monthly mean air temperature for Brazil. Theoretical and Applied Climatology, 113, 407-427. https://doi.org/10.1007/s00704-012-0796-6

Alvares, C. A., Stape, J. L.; Sentelhas, P. C., Gonçalves, J. L. M. and Sparovek, G. (2013b). Köppen’s climate classification map for Brazil. Meteorologische Zeitschrift, 22, 711-728. https://doi.org/10.1127/0941-2948/2013/0507

Bustos, P., Caprettini, B. and Ponticelli, J. (2016). Agricultural productivity and structural transformation: evidence from Brazil. American Economic Review, 106, 1320-1365. https://doi.org/10.1257/aer.20131061

Brazil. Ministério das Minas e Energia. (1973-1986). Projeto Radambrasil. Levantamento de recursos naturais. Rio de Janeiro, Brazil: IBGE.

Camargo, A. P., Marin, F. R., Sentelhas, P. C. and Picini, A. G. (1999). Ajuste da equação de Thornthwaite para estimar a evapotranspiração potencial em climas áridos e superúmidos, com base na amplitude térmica. Revista Brasileira de Agrometeorologia, 7, $251-257$.

Cooper, M., Mendes, L. M. S., Silva, W. L. C. and Sparovek, G. (2005). National soil profile database for Brazil available to international scientists. Soil Science Society of America Journal, 69, 649-652. https://doi.org/10.2136/sssaj2004.0140

Edreira, J. I. R., Mourtzinis, S., Conley, S. P., Roth, A. C., Ciampitti, I. A., Licht, M. A., Kandel, H., Kyveryga, P. M., Lindsey, L. E., Mueller, D. S., Naeve, S. L., Nafziger, E., Specht, J. E., Stanley, J., Staton, M. J. and Grassini, P. (2017). Assessing causes of yield gaps in agricultural areas with diversity in climate and soils. Agricultural and Forest Meteorology, 247, 170-180. https://doi.org/10.1016/j.agrformet.2017.07.010 
Edreira, J. I. R.; Cassman, K. G., Hochman, Z., van Ittersum, M. K., van Bussel, L., Claessens. L. and Grassini, P. (2018). Beyond the plot: technology extrapolation domains for scaling out agronomic science. Environmental Research Letters, 13, 054027. https://doi. org/10.1088/1748-9326/aac092

Licker, R., Johnston, M., Foley, J. A., Barford, C., Kucharik, C. J., Monfreda, C. and Ramankutty, N. (2010). Mind the gap: how do climate and agricultural management explain the 'yield gap' of croplands around the world? Global Ecology and Biogeography, $19,769-782$. https://doi.org/10.1111/j.1466-8238.2010.00563.x

López-Ovejero, R. F., Garcia, A. G., Carvalho, S. J. P., Christoffoleti, P. J., Dourado Neto, D., Martins, F. and Nicolai, M. (2005). Using thermal units for estimating critical period of weed competition in off-season maize crop. Journal of Environmental Science and Health, Part B, 40, 1-11.

Marin, F. R., Lopes-Assad, M. L., Assad, E. D., Vian, C. E. and Santos, M.C. (2008). Sugarcane crop efficiency in two growing seasons in São Paulo State, Brazil. Pesquisa Agropecuária Brasileira, 43, 1449-1455. https://doi.org/10.1590/S0100-204X2008001100002

Marin, F. R. and Carvalho, G. L. (2012). Spatio-temporal variability of sugarcane yield efficiency in the state of São Paulo, Brazil. Pesquisa Agropecuária Brasileira, 47, 149-156. https://doi.org/10.1590/S0100-204X2012000200001

Marin, F. R. and Jones, J. W. (2014). Process-Based simple model for simulating sugarcane growth and production. Scientia Agricola 71, 1-16. https://doi.org/10.1590/S0103-90162014000100001

Marin, F. R., Ribeiro, R. V. and Marchiori, P. E. R. (2014). How can crop modeling and plant physiology help to understand the plant responses to climate change? A case study with sugarcane. Theoretical and Experimental Plant Physiology, 26, 49-63. https://doi. org/10.1007/s40626-014-0006-2

Martinelli, L. A., Naylor, R., Vitousek, P. M. and Moutinho, P. (2010). Agriculture in Brazil: impacts, costs and opportunities for a sustainable future. Current Opinion in Environmental Sustainability, 2, 431-438. https://doi.org/10.1016/j.cosust.2010.09.008

Mourtzinis, S., Edreira, J. I. R., Grassini, P., Roth, A. C., Casteel, S. N., Ciampitti, I. A., Kandel, H. J., Kyveryga, P. M., Licht, M. A., Lindsey, L. E., Mueller, D. S., Nafziger, E. D., Naeve, S. L., Stanley, J., Staton, M. J. and Conley, S. P. (2018). Sifting and winnowing: Analysis of farmer field data for soybean in the US North-Central region. Field Crops Research, 221, 130-141. https://doi.org/10.1016/j.fcr.2018.02.024

Pardey, P. G., Alaston, J. M., Chan-Kang, C., Magalhães, E. C. and Vosti, S. A. (2006). International and institutional R\&D spillovers: attribution of benefits among sources for Brazil's new crop varieties. American Journal of Agricultural Economics, 88, 104-123. https:// doi.org/10.1111/j.1467-8276.2006.00841.x

Pascale, A. J., Villegas, J. A. and Medina, L. F. (1973). Aptitud agroclimática del Noroeste Argentino para el cultivo de la soja. Revista Agronómica del Noroeste Argentino, 10, 173-203.

Silva, E. H. F. M., Gonçalves, A. O., Pereira, R. A., Fattori Júnior, I. M., Sobenko, L. R. and Marin, F. R. (2019). Soybean irrigation requirements and canopy-atmosphere coupling in Southern Brazil. Agricultural Water Management, 218, 1-7. https://doi.org/10.1016/j.agwat.2019.03.003

Souza, T. T., Antolin, L. A. S., Bianchini, V. J. M., Pereira, R. A. A., Silva, E. H. F. M. and Marin, F. R. (2019). Longer crop cycle lengths could offset the negative effects of climate change on Brazilian maize. Bragantia, 78, 622-631. https://doi.org/10.1590/1678-4499.20190085

Tiffin, R. and Irz, X. (2006). Is agriculture the engine of growth? Agricultural Economics, 35,79-89. https://doi.org/10.1111/j.1574-0862.2006.00141.x Tomassella, J., Hodnett, M. G. and Rossato, L. (2000). Pedotransfer Functions for the estimation of soil water retention in Brazilian soils. Soil Science Society of America Journal, 64, 327-338. https://doi.org/10.2136/sssaj2000.641327x

Van Bussel, L. G. J., Grassini, P., van Wart, J., Wolf, J., Claessens, L., Yang, H., Boogaard, H., Groot, H., Saito, K., Cassman, K. G. and van Ittersum, M. K. (2015). From field to atlas: Upscaling of location-specific yield gap estimates. Field Crops Research, 177, 98-108. https:// doi.org/10.1016/J.FCR.2015.03.005 
Van Genuchten, M. T. (1980). A closed form equation for predicting the hydraulic conductivity of unsaturated soils. Soil Science Society of America Journal, 44, 892-898. https://doi.org/10.2136/sssaj1980.03615995004400050002x

Van Ittersum, M. K., Cassman, K. G., Grassini, P., Wolf, J., Tittonell, P. and Hochman, Z. (2013). Yield gap analysis with local to global relevance - A review. Field Crop Research, 143, 4-17. https://doi.org/10.1016/j.fcr.2012.09.009

Van Wart, J., van Bussel, L. G. J., Wolf, J., Licker, R., Grassini, P., Nelson, A., Boogaard, H., Gerber, J., Mueller, N. D., Claessens, L., van Ittersumb, M. K. and Cassman, K. G. (2013). Use of agro-climatic zones to upscale simulated crop yield potential. Field Crops Research, 143, 44-55. https://doi.org/10.1016/j.fcr.2012.11.023

Vianna, M. S., Nassif, D. S. P., Carvalho, K. S. and Marin, F. R. (2020). Modelling the trash blanket effect on sugarcane growth and water use. Computers and Electronics in Agriculture, 172, 105361. https://doi.org/10.1016/j.compag.2020.105361

Warrington, I. J. and Kanemasu, E. T. (1983). Corn growth response to temperature and photoperiod I. Seedling Emergence, Tassel Initiation and Anthesis. Agronomy Journal, 75, 749-754. https://doi.org/10.2134/agronj1983.00021962007500050008x 


\section{SUPLEMENTARY FILES}

(a) $60^{\circ} 0^{\prime} 0 " \mathrm{~W} 55^{\circ} 0^{\prime} 0^{\prime \prime} \mathrm{W} 50^{\circ} 0^{\prime} 0^{\prime \prime} \mathrm{W} 45^{\circ} \mathrm{O}^{\prime} \mathrm{O}^{\prime \prime} \mathrm{W} 40^{\circ} \mathrm{O}^{\prime} \mathrm{O}^{\prime \prime} \mathrm{W} 35^{\circ} 0^{\prime} \mathrm{O}^{\prime \prime W}$

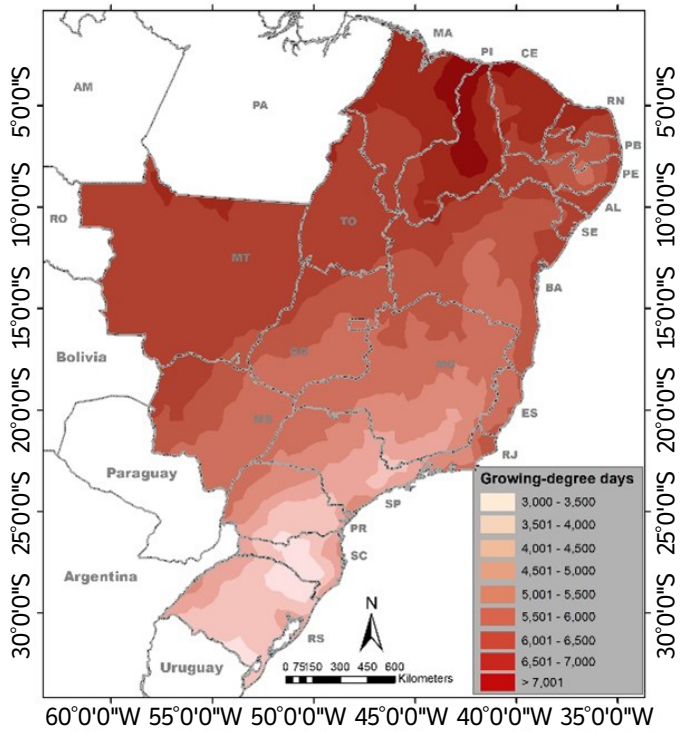

(b)

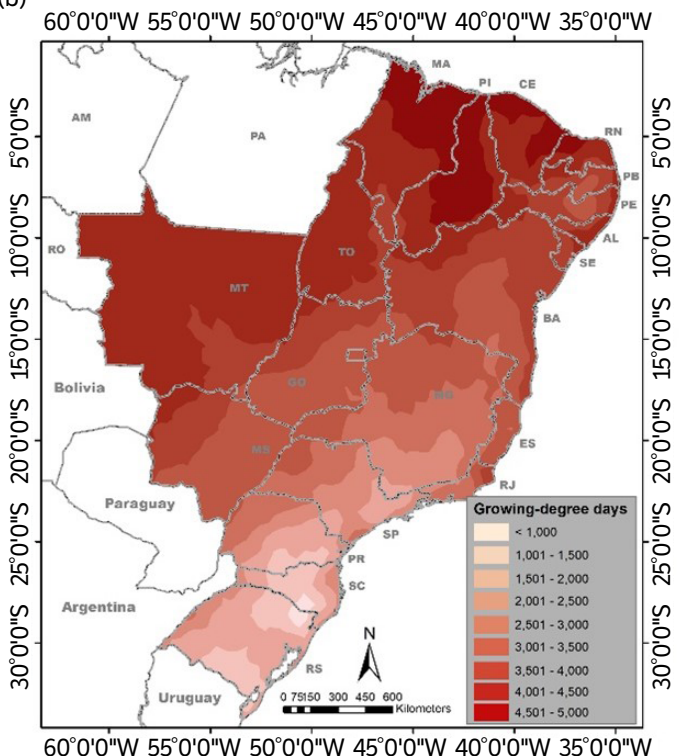

(c) $60^{\circ} 0^{\prime} 0^{\prime \prime} \mathrm{W} 55^{\circ} 0^{\prime} 0 " \mathrm{~W} 50^{\circ} 0^{\prime} 0^{\prime \prime} \mathrm{W} 45^{\circ} 0^{\prime} 0 " \mathrm{~W} 40^{\circ} 0^{\prime} 0^{\prime \prime} \mathrm{W} 35^{\circ} 0^{\prime} 0 " \mathrm{~W}$

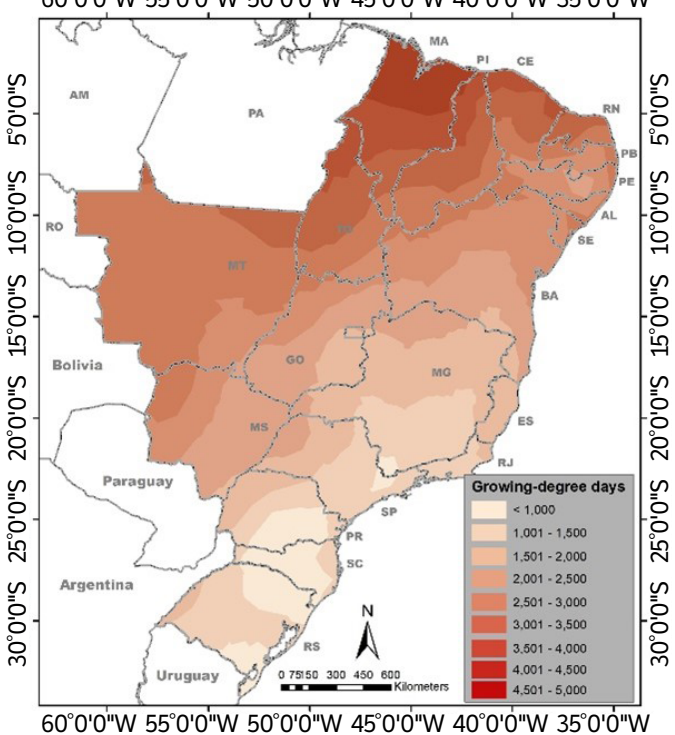

Figure S1. Spatial variation of crop-specific growing degree-days for maize (a), soybean (b) and sugarcane (c) of the main agricultural states of Brazil. 


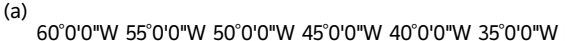

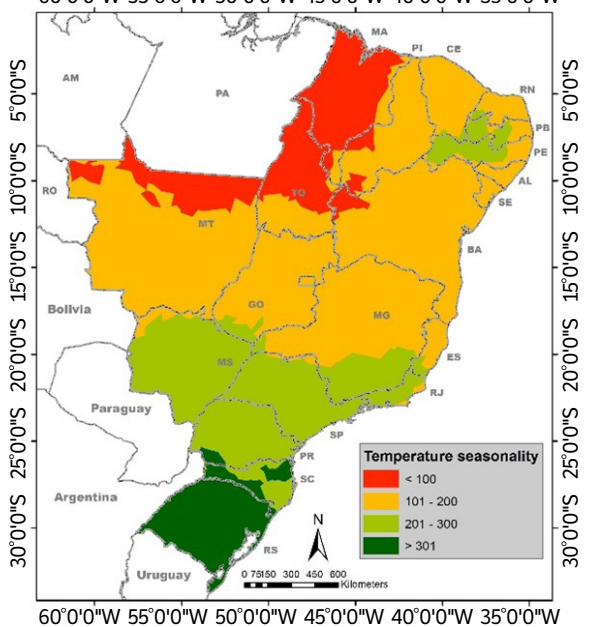

(b)

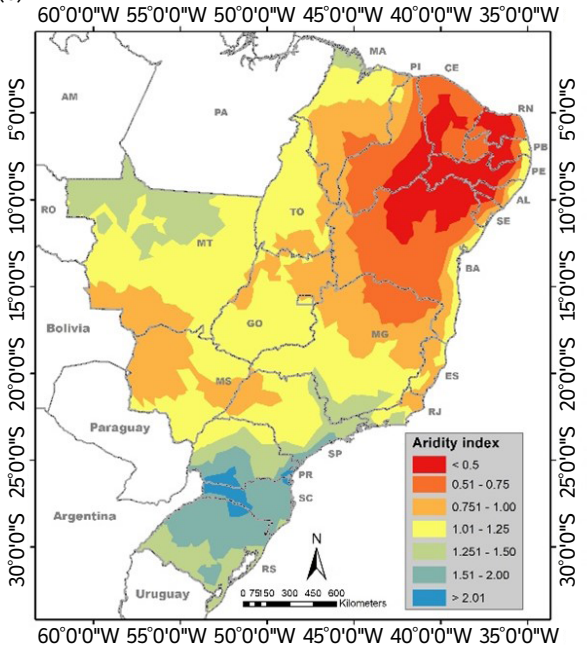

Figure S2. Spatial variability of temperature seasonality (a) and aridity index (b) in the main agricultural states of Brazil.

(a)

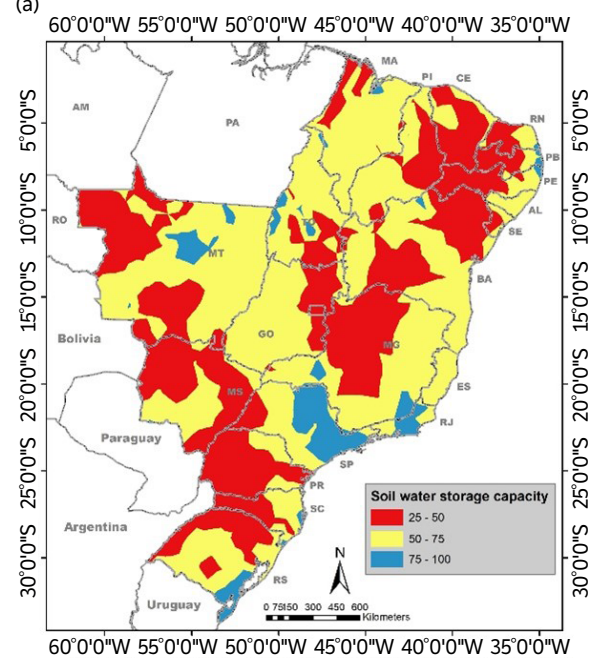

(b)

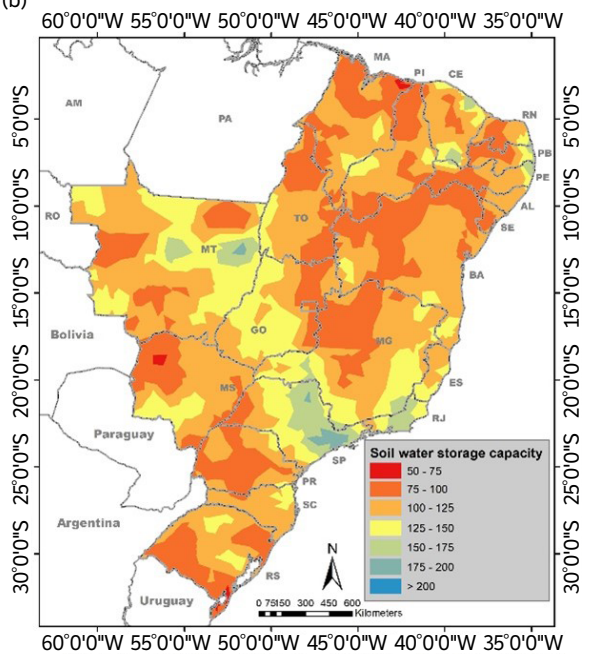

(c) $60^{\circ} 0^{\prime} 0^{\prime \prime W} 55^{\circ} 0^{\prime} 0^{\prime \prime W} 50^{\circ} 0^{\prime} 0^{\prime \prime W} 45^{\circ} 0^{\prime} 0 " W$ 40 $40^{\circ} 0^{\prime} 0^{\prime W} 35^{\circ} 0^{\prime} 0^{\prime \prime} \mathrm{W}$

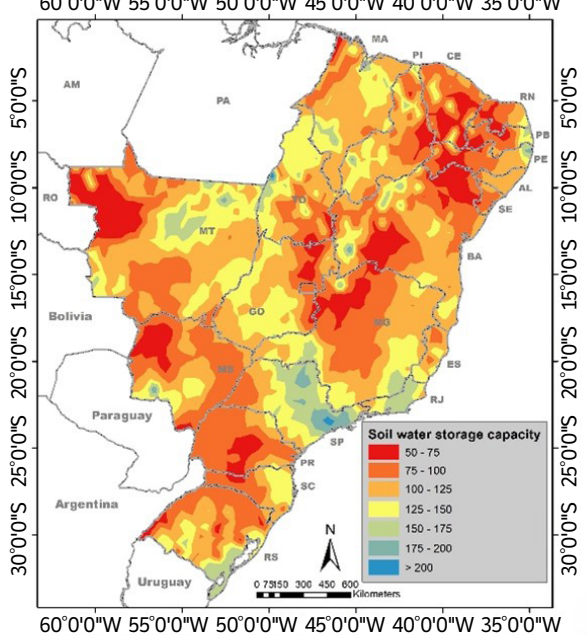

Figure S3. Spatial variation of crop-specific total available water $(\mathrm{mm})$ in soil for maize (a), soybean (b) and sugarcane (c) in the main agricultural states of Brazil. 